\title{
Trade, FDI, and International Technology Diffusion
}

\author{
Bin Xu \\ University of Florida \\ Jianmao Wang \\ University of Florida and CEIBS
}

\begin{abstract}
This paper examines international trade and foreign direct investment as channels for technology diffusion among industrialized countries. We find strong empirical support for capital goods trade as a channel for international technology diffusion and some evidence that multinational enterprises (outward FDI) transmit foreign technology back to the home country. We find no evidence that inward FDI is a significant channel for international technology diffusion among industrialized countries. Our results also show that technology diffuses in disembodied forms, with countries that are farther from the world technology frontier benefiting more.
\end{abstract}

- JEL Classifications: F15, F21, O40

- Key Words: International Trade, FDI, Technology Diffusion

\section{Introduction}

A handful of industrialized countries perform almost all the world's R\&D. In 1990, OECD countries accounted for 96\% of total world R\&D expenditures (Coe, Helpman, and Hoffmaister (1997), p. 134). Moreover, innovative activity is further concentrated in a few technologically leading countries. In the late 1980s,

\footnotetext{
* Corresponding Address: Bin Xu, Department of Economics, University of Florida, Gainesville, FL 32611, USA; Email: xub@dale.cba.ufl.edu; Phone: +352-392-0122; Fax: +352-392-7860. We thank two anonymous referees for useful comments and suggestions. The first author acknowledges financial support from the Warrington College of Business Administration and the DSRD Program of the University of Florida. All errors are our responsibility.

C 2000-Institute for International Economics, Sejong Institution. All rights reserved.
} 
the United States, Japan, Germany, the United Kingdom, and France employed over $80 \%$ of the OECD's research scientists and engineers (Eaton and Kortum (1999), p. 540). A casual look at world productivity data reveals, however, that the benefits of R\&D are much more evenly distributed in the world than the expenditures on $\mathrm{R} \& \mathrm{D}$; this evidence suggests that technology diffuses internationally. The interesting issue for researchers is how technology diffuses across national borders and what is the magnitude of the diffusion.

Two leading candidates for diffusion channels are international trade and foreign direct investment (FDI). Recent theory suggests two broad ways in which trade and FDI contribute to productivity growth: by making available products and services that embody foreign technology, and by providing foreign technologies and other types of knowledge that would otherwise be unavailable or very costly to acquire (Helpman (1997), p. 5).

International trade as a channel for R\&D spillovers has received much study recently. Using different approaches, researchers have reached the same qualitative conclusion that international trade transmits a significant amount of knowledge. While the quantitative estimates differ, the consensus seems that the total amount of trade-related R\&D spillovers are large but there exist great asymmetries in magnitude between countries. For example, Coe and Helpman (1995; henceforth $\mathrm{CH}$ ) estimated that R\&D investment in G7 countries produces an extra $30 \%$ return (in addition to the domestic rate of return) by raising total factor productivity in the smaller industrial countries. Eaton and Kortum (1996) and Bernstein and Mohnen (1998) found that R\&D spillovers from the United States to Japan are much more significant than R\&D spillovers from Japan to the United States.

Compared to international trade, FDI as a diffusion channel has received relatively little study. The FDI mechanism involves multinational enterprises and is inherently more complex than the trade mechanism. Moreover, FDI data are of poorer quality than trade data. There is no agreement among researchers on the role of FDI in international technology diffusion even at the qualitative level. Lichtenberg and van Pottelsberghe de la Potterie (1996; henceforth LP) found that inward FDI flows did not carry knowledge spillovers among OECD countries during the period 1971-90, while Hejazi and Safarian (1999) found significant R\&D spillovers in FDI from six largest industrial countries to smaller OECD countries during the same period. ${ }^{1}$ A recent paper by $\mathrm{Xu}$ (2000) found that

\footnotetext{
${ }^{1}$ See also Hejazi and Safarian (1996) in which they found significant R\&D spillovers in FDI from the United States to other OECD countries.
} 
technology transfer of U.S. multinational enterprises contributed to the productivity growth in developed countries but not in less developed countries.

Disagreements notwithstanding, there is more and more awareness of methodology and measurement in the recent literature on international technology diffusion. For example, the $\mathrm{CH}$ approach has been modified in several directions. Lichtenberg and van Pottelsberghe de la Potterie (1998) identified a misspecification in one of CH's regressions and also proposed an alternative measure of foreign R\&D spillovers. Engelbrecht (1997) pointed out the need to consider the role of human capital. Coe, Helpman, and Hoffmaister (1997) found that trade in capital goods measures the trade-related spillover channel better than total trade. Xu and Wang (1999) showed the importance of controlling for nontrade channels in assessing the impact of trade in international technology diffusion. While there are still many unresolved issues, researchers in this area know both the merits and the limitations of existing approaches much better now than a few years ago. ${ }^{2}$

In this paper we add two extensions to the literature. First, we use a sample of 21 OECD countries over the period 1971-90 to examine the role of capital goods trade as a channel for international R\&D spillovers. This study extends $\mathrm{Xu}$ and Wang (1999), who investigated the issue with a sample over the period 1983-90. Such an extension is useful for comparison with Coe and Helpman (1995) and other studies, all of which used the sample period 1971-90. The present study also modifies the regression specification of Xu and Wang (1999) by controlling for a "technology gap" effect. Second, we use a sample of 13 OECD countries over the period 1983-90 to investigate inward FDI and outward FDI as spillover channels. While the availability of FDI data limits both the country and time dimensions of the sample and the quality of FDI data is poorer than the trade data, this study allows an examination of trade and FDI as simultaneous channels for international R\&D spillovers. The results from this study complement those from LP (1996) and Hejazi and Safarian $(1996,1999)$ and provide a useful reference point for future research on this important subject.

We organize the remainder of the paper as follows. In section II we discuss

\footnotetext{
${ }^{2}$ One criticism of the $\mathrm{CH}$ approach is Keller (1998), who found that R\&D spillovers constructed with randomly created trade data explain more of the productivity variation than the $\mathrm{CH}$ spillover measure constructed with imports data. Coe and Hoffmaister (1999) responded by showing that Keller's random shares are essentially simple averages with a random error; they interpreted Keller's result as an indication of the public good nature of knowledge.
} 
measurement of R\&D spillovers and specify regression equations. In section III we describe the trade and FDI data used in our investigation. In section IV we report the main empirical findings. In section $\mathrm{V}$ we conclude.

\section{Framework}

Our empirical investigation adopts a Cobb-Douglas production function estimation approach. A country produces output $(Y)$ using labor $(L)$, physical capital $(K)$, and knowledge capital $(S)$, subject to a Cobb-Douglas production function, $Y=A L^{\alpha} K^{\beta} S^{\gamma}$. Defining total factor productivity (TFP) as $F=Y / L^{\alpha} K^{\beta}$, we obtain $F=A S^{\gamma}$. For an open economy, $S$ depends on both domestic knowledge capital $\left(S^{d}\right)$ and knowledge spillovers from other countries $\left(S^{f}\right)$. Following $\mathrm{CH}$, we assume that $S=\left(S^{d}\right)^{\delta}\left(S^{f}\right)^{\phi}$. This leads, in a panel data setting, to the following regression specification:

$$
\log F_{i t}=c_{i t}+\alpha_{i t}^{d} \log S_{i t}^{d}+\alpha_{i t}^{f} \log S_{i t}^{f}+\varepsilon_{i t}
$$

where $i$ and $t$ are indices of country and time, $c$ is a composite intercept term including both country- and time-specific fixed effects, $\alpha^{d}$ and $\alpha^{f}$ are elasticities of TFP with respect to domestic R\&D capital and foreign R\&D spillovers, and $\varepsilon$ is an error term.

\section{A. Measures of $R \& D$ Spillovers}

The first step in our investigation is to measure foreign R\&D spillovers $\left(S^{f}\right)$. A common approach in the literature is to measure $S^{f}$ as a weighted sum of domestic R\&D capital stocks of the countries that form the source of the spillovers. Letting $J$ be a set of countries which transmit knowledge to country $i$, we have

$$
S_{i t}^{f}=\Sigma_{j} W_{i j t} S_{j t}^{d}, \quad j \in J .
$$

The weight $W_{i j}$ is the fraction of country $j$ 's R\&D that spills over to country $i$.

There are two alternative weighting schemes in the recent literature on international R\&D spillovers. CH (1995) proposed the following weighting scheme:

$$
S_{i t}^{f-C H}(M)=\sum_{j \neq i} \frac{M_{i j t}}{M_{i t}} S_{j t}^{d}
$$

where $M$ is the weight variable reflecting the channel for $\mathrm{R} \& \mathrm{D}$ spillovers, 
$M_{i t}=\Sigma_{j \neq i} M_{i j t}$. In $\mathrm{CH}$, for example, the weight variable is imports. Thus, $\mathrm{CH}$ measured foreign $R \& D$ spillovers as bilateral import share weighted sum of $R \& D$ capital stocks of trade partners. In this study we will use three weight variables: capital goods trade (KM), inward foreign direct investment (FDI), and outward foreign direct investment (OFDI).

LP (1996) proposed an alternative spillover measure:

$$
S_{i t}^{f-L P}(M)=\sum_{j \neq i} \frac{M_{i j t}}{Y_{j t}} S_{j t}^{d}
$$

where $Y_{j t}$ denotes GDP of source country $j$ at time $t$. Note that the "weights" in the LP measure are exports-GDP ratios of source countries and do not sum to one.

There is no consensus among researchers on the choice between the $\mathrm{CH}$ and LP spillover measures; neither is derived from theoretical models. We will use both measures in our investigation as a robustness check of our results.

\section{B. Channels for R\&D Spillovers}

The second step in our investigation is to specify channels for R\&D spillovers. Knowledge transmits through various channels. One limitation of CH (1995) is that they considered only the trade channel. Some more recent papers have attempted to model multiple channels. LP (1996) considered technology diffusion through imports, inward FDI, and outward FDI between OECD countries. Hejazi and Safarian (1999) examined imports and inward FDI as conduits for R\&D spillovers from six largest industrial countries to smaller industrial countries. Xu and Wang (1999) estimated the contribution of R\&D spillovers embodied in capital goods trade and the contribution of disembodied foreign R\&D spillovers. $\mathrm{Xu}$ (2000) examined capital goods trade and multinational corporation technology transfer as two simultaneous channels for technology diffusion.

In this paper we consider three channels for R\&D spillovers. First, we specify capital goods trade as a conduit for technology diffusion. Xu and Wang (1999) showed that knowledge in trade flows is mainly embodied in capital goods trade. Second, we specify inward FDI as another R\&D spillover channel. Hejazi and Safarian (1999) summarized theoretical arguments for inward FDI as a channel for technology diffusion. Third, we consider outward FDI as another possible channel for technology diffusion. LP (1996) argued that one of the goals for multinational enterprises to establish subsidiaries abroad is to benefit from the foreign scientific base. 


\section{Regression Specifications}

We denote $S^{f}(K M), S^{f}(F D I)$, and $S^{f}(O F D I)$ as foreign R\&D spillovers through the channels of capital goods imports, inward FDI, and outward FDI, respectively. Following $\mathrm{Xu}$ and Wang (1999), we use an unweighted spillover variable, $S^{f}(U W)=\Sigma_{j \neq i} S_{j t}^{d}$, as a proxy for disembodied R\&D spillovers. Following Engelbrecht (1997), we use a human capital variable $H$. To estimate equation (1), we impose some restrictions. First, we assume that country- and time-fixed effects are separable, $c_{i t}=c_{i}+c_{t}$. Second, we assume that TFP elasticities are invariant to time in the sample period. Third, we follow $\mathrm{CH}$ to assume that TFP elasticities with respect to domestic R\&D capital differ only between G7 and non-G7 countries. Fourth, when the $\mathrm{CH}$ spillover measure is used, we follow $\mathrm{CH}$ to assume that TFP elasticities with respect to trade-embodying R\&D spillovers are proportional to the share of capital goods imports in GDP; when the LP spillover measure is used, we assume that the elasticities are the same for all countries. Taking all these into account, we have the following regression equation:

$$
\begin{aligned}
\log F_{i t}=c_{i} & +c_{t}+b_{1} \log S_{i t}^{d}+b_{2} G 7 \log S_{i t}^{d}+b_{3} \log S_{i t}^{f}(K M)+b_{4} \log S_{i t}^{f}(F D I) \\
& +b_{2} \log S_{i t}^{f}(O F D I)+b_{6} \log S_{i t}^{f}(U W)+b_{7} \log H_{i t}+e_{i t}
\end{aligned}
$$

where G7 is a dummy variable for the seven major industrial countries, $H$ is a human capital stock, and $e$ is an error term. The parameter $b_{3}$ equals $\beta_{3} m_{i t}$ when the $\mathrm{CH}$ measure is used, where $m_{i l}=K M_{i t} / \mathrm{GDP}_{i t}{ }^{3}$

It is important to point out that TFP and R\&D variables are nonstationary but there is no confirmation as to whether they are cointegrated (see tables 2 and 3 of $\mathrm{CH}$ ). If the variables are nonstationary but cointegrated, regressions that use levels of variables, such as equation (5), have the advantage of utilizing the information embodied in the long-run relationship between the variables. However, the possibility that the estimated equations are not cointegrated is troublesome. Unfortunately cointegration tests of panel data have not been fully developed despite the recent progress in Im, Pesaran, and Shin (1997). In view of this, we take first difference of equation (5) to obtain:

$$
\Delta \log F_{i t}=\Delta c_{t}+b_{1} \Delta \log S_{i t}^{d}+b_{2} G 7 \Delta \log S_{i t}^{d}+b_{3} \Delta \log S_{i t}^{f}(K M)+b_{4} \Delta \log S_{i t}^{f}(F D I)
$$

\footnotetext{
${ }^{3}$ The variable $m$ accounts for the effect of trade openness that is not captured in the $\mathrm{CH}$ measure of foreign $R \& D$ spillovers, which accounts for the effect of trade composition on the size of R\&D spillovers. Because trade and FDI openness are correlated, we do not add an FDI openness variable to the regression when trade openness is already controlled for.
} 


$$
+b_{5} \Delta \log S_{i t}^{f}(O F D I)+b_{6} \Delta \log S_{i t}^{f}(U W)+b_{7} \Delta \log H_{i t}+b_{8} \log G A P+\mu_{i t}
$$

In equation (6), $\Delta X_{t}=X_{t}-X_{t-1}$ for variable $X$. While some information is lost in differencing, equation (6) allows more reliable inference of statistical significance of variables. Notice that we add the variable GAP in equation (6). This variable measures the technology gap between a country's technology level and the world technology frontier. Theoretical models (e.g. Barro and Sala-i-Martin (1997)) have identified this variable to be important in the process of international technology diffusion.

\section{Data}

Our investigation requires bilateral trade and FDI data. We use imports of machinery and transport equipment (SITC 7) as a proxy for imports of capital goods. Xu and Wang (1999) used data from the OECD's Foreign Trade by Commodities, which are available for years after 1983. In this study we use data from a different source, which allows us to extend the beginning year of the sample to 1971. The data are from an annual publication of the United Nations entitled Bulletin of Statistics on World Trade in Engineering Products. This publication contains bilateral trade data for SITC 7 from 1963 to $1990{ }^{4}$

Bilateral FDI data are from the OECD's International Direct Investment Statistics Yearbook. This publication contains both flow and stock data available for years after 1982. We use FDI stocks in computing FDI-embodying R\&D spillovers since they better measure the magnitude of multinational enterprises than FDI flows. The stock data in the publication are collected from statistical sources of each country. For some countries (Australia, Austria, Canada, France, Germany, the Netherlands, Norway, Sweden, Switzerland, UK, US), FDI stock figures are based on company surveys. For other countries (Italy, Japan), FDI stock data are derived from cumulative value of FDI flows. ${ }^{5}$ Because of missing data, we are only able to construct a sample of the above 13 countries. ${ }^{6}$ The FDI stock figures from the OECD publication are in year-end values beginning at 1982. Since R\&D spillover variables are valued at the beginning of each year, our sample period starts from 1983.

\footnotetext{
${ }^{4}$ There is little difference between the OECD and UN data for the overlapping years after 1983. ${ }^{5}$ Details of FDI data are described in "Technical Notes" of the publication.

${ }^{6}$ There are still a few missing values for the 13 countries, which we estimate using FDI flow data.
} 
There are two issues regarding the international comparability of FDI data. First, the definitions of FDI differ between countries. To qualify as FDI, the ownership threshold is $10 \%$ in Australia (after 1986), Austria, Canada, Norway, Sweden, Switzerland, and the United States; it is $20 \%$ in France, Germany, Italy, the United Kingdom, and 25\% in Australia (before 1986); there is no minimum threshold in Japan and the Netherlands. Second, FDI stocks are measured in market value in some countries (e.g. Australia) but in book values in others (e.g. Norway, the United States). Due to lack of information, we are not able to do any adjustment to overcome the incomparability in FDI data. ${ }^{7}$ Therefore, the reader should be cautious in interpreting our results based on FDI data.

TFP and domestic R\&D capital data are from CH (1995). It is worth noting that our study uses $R \& D$ variables expressed in values rather than in indices, and hence avoids a misspecification identified by LP (1998). ${ }^{8}$ The technology gap variable $(G A P)$ is measured by a country's TFP level relative to that of the United States in previous year. ${ }^{9}$ The human capital variable $(H)$ is measured by average years of total school attainment; data are from Barro and Lee (1996). GDP data are obtained from the World Bank.

To summarize, we have prepared two samples for our investigation. First, we have a sample of 21 OECD countries over the period 1971-90 to examine capital goods trade as a spillover channel. Second, we have a sample of 13 OECD countries over the period 1983-90 to examine the role of FDI. Tables A1-A3 in the appendix provide information on the distribution of capital goods trade, inward FDI, and outward FDI in the OECD countries. ${ }^{10}$

\section{Results}

We report regression results in Tables 1-4. All regressions are run using

\footnotetext{
${ }^{7}$ In addition, we find that the FDI stock reported by the destination country and the same FDI stock reported by the origin country are quite different. Being unable to judge the relative reliability of the data, we have to take the average of these two.

${ }^{8} \mathrm{Coe}$ and Hoffmaister (1999) showed that a modification of the $\mathrm{CH}$ specification would avoid the misspecification while still allowing the use of indexed data.

${ }^{9}$ Because TFP figures from CH (1995) are in indices, we calculate TFP levels based on data in the Penn World Tables, Mark 5.6. The capital income share is assumed to be 0.3 .

${ }^{10}$ The correlation between the capital goods trade and inward FDI series is 0.6731 , and the correlation between the capital goods trade and outward FDI series is 0.5765. Inward and outward FDI series have a correlation of 0.8912 .
} 
Table 1. Regression Results

\begin{tabular}{|l|c|c|c|c|}
\hline Regression number & 1.1 & 1.2 & 1.3 & 1.4 \\
\hline \multirow{2}{*}{$\log S^{d}$} & 0.068 & 0.006 & 0.005 & -0.004 \\
& $(0.009)$ & $(0.013)$ & $(0.010)$ & $(0.012)$ \\
\hline \multirow{2}{*}{ G7 $\log S^{d}$} & 0.138 & 0.121 & 0.100 & 0.101 \\
& $(0.018)$ & $(0.017)$ & $(0.017)$ & $(0.017)$ \\
\hline \multirow{2}{*}{$m \log S^{f-C H}(K M)$} & 0.186 & 0.088 & & \\
\hline \multirow{2}{*}{$\log S^{-L P}(K M)$} & $(0.042)$ & $(0.041)$ & & 0.082 \\
\hline \multirow{2}{*}{$\log S^{f}(U W)$} & & & 0.103 & $(0.012)$ \\
\hline \multirow{2}{*}{$\log H$} & & & & 0.075 \\
& & $(0.040)$ & & $(0.041)$ \\
\hline$R^{2}$ & & -0.001 & & -0.007 \\
\hline$R^{2}$ adjusted & & $(0.040)$ & & $(0.036)$ \\
\hline
\end{tabular}

Notes: The dependent variable is log TFP. All equations include unreported country-specific constants. $S^{d}$ is domestic R\&D capital stock; $S^{f-C H}(K M)$ and $S^{f-L P}(K M)$ are the CH and LP measures of foreign R\&D spillovers embodied in capital goods imports, respectively; $m$ is ratio of capital goods imports to GDP, previous year; $S^{f}(U W)$ is unweighted foreign R\&D spillovers; $H$ is average years of total school attainment; $\mathrm{G} 7$ is a dummy variable for the seven major countries. Numbers in parentheses are heteroscedasticity-corrected standard errors, which are in general biased because of nonstationarity in variables. (Pooled Data 1971-90 for 21 OECD Countries, 420 Observations, OLS).

ordinary least squares with White's heteroscedasticity-consistent covariance estimation method.

\section{A. Capital Goods Trade}

Table 1 reports results from regressions that use equation (5). All regressions include unreported country-specific constants. ${ }^{11}$ The dependent variable is log (TFP).

In Table 1 we report estimated standard errors but do not relate them to levels of statistical significance. The reason is that estimated standard errors are in general biased when variables are nonstationary. The point estimates in Table 1 offer useful information on TFP effects of domestic R\&D capital and foreign R\&D spillovers. In regression (1.1), we find large estimated elasticities of TFP with respect to foreign $R \& D$ spillovers in capital goods trade and with respect to

\footnotetext{
${ }^{11}$ To compare with existing studies (e.g. $\left.\mathrm{CH}, \mathrm{LP}\right)$, we do not include time-specific constants. Including time-specific constants would change some of the results.
} 
Table 2. Regression Results

\begin{tabular}{|l|c|c|c|c|}
\hline Regression number & 2.1 & 2.2 & 2.3 & 2.4 \\
\hline \multirow{2}{*}{$\Delta \log S^{d}$} & -0.032 & -0.031 & -0.033 & -0.035 \\
& $(0.025)$ & $(0.029)$ & $(0.025)$ & $(0.029)$ \\
\hline \multirow{2}{*}{$\Delta \mathrm{G} 7 \log S^{d}$} & 0.090 & 0.089 & 0.087 & 0.085 \\
& $(0.029)^{* * *}$ & $(0.028)^{* * *}$ & $(0.029)^{* * *}$ & $(0.027)^{* * *}$ \\
\hline \multirow{2}{*}{$\Delta m \log S^{f-C H}(K M)$} & 0.113 & 0.112 & & \\
\hline \multirow{2}{*}{$\Delta \log S^{f-L P}(K M)$} & $(0.034)^{* * *}$ & $(0.035)^{* * *}$ & & 0.050 \\
\hline \multirow{2}{*}{$\Delta \log S^{f}(U W)$} & & & & 0.049 \\
& & -0.024 & & $(0.011)^{* * *}$ \\
\hline \multirow{2}{*}{$\Delta \log H$} & & $(0.121)$ & & -0.065 \\
& & 0.001 & & $0.122)$ \\
\hline \multirow{2}{*}{$\log G A P$} & & $-0.050)$ & & $(0.089)$ \\
\hline$R^{2}$ & & $(0.008)^{* * *}$ & & -0.022 \\
\hline$R^{2}$ adjusted & 0.310 & 0.342 & 0.336 & 0.368 \\
\hline
\end{tabular}

Notes: The dependent variable is $\Delta \log$ TFP. $\Delta X=X_{\mathrm{t}}-X_{\mathrm{t}-1}$ for variable $X$. All equations include unreported time-specific constants. GAP is TFP relative to that of the United States, previous year. See notes to table 1 for definitions of other variables. Numbers in parentheses are heteroscedasticity-corrected standard errors. "****" indicates statistical significance at the $1 \%$ level. (Pooled Data 1972-90 for 21 OECD Countries, 399 Observations, OLS)

domestic R\&D capital in G7 countries. Regression (1.2) includes an additional variable $S^{f}(U W)$ as a proxy for disembodied R\&D spillovers. We find, as Xu and Wang (1999), that the estimated effect of trade-embodying R\&D spillovers is greatly reduced once disembodied $R \& D$ spillovers are controlled for. In regressions (1.3) and (1.4) we adopt the LP measure of foreign R\&D spillovers instead of the $\mathrm{CH}$ measure and find similar results.

In Table 2 we run the same regressions of Table 1 but use equation (6) as specification. The variables in this equation are first differences of the variables in equation (5). Although some information is lost in differencing, the estimated standard errors in Table 2 can be used to make inference on statistical significance of variables.

Table 2 confirms two findings of Xu and Wang (1999). First, capital goods trade is an important channel for R\&D spillovers in the OECD. Whether we use the $\mathrm{CH}$ or the LP measure, the variable $S^{f}(K M)$ is statistically significant and has a relatively large estimated coefficient. Second, the domestic R\&D variable is statistically significant in G7 countries but insignificant in non-G7 countries. 
In Table 2 we include a "technology gap" variable $(G A P)$. The variable is statistically significant at the $1 \%$ level. The larger the technology gap, the lower the value of $G A P$, and the faster the TFP growth. This result may be interpreted as evidence of international technology diffusion in disembodied forms (Barro and Sala-i-Marin (1997)). Notice that the estimated coefficient on $S^{f}(U W)$ is statistically indifferent from zero, which may be a result of loss of information due to differencing and may also be a result of $S^{f}(\mathrm{UW})$ being an inaccurate measure of disembodied R\&D spillovers.

\section{B. Foreign Direct Investment}

Tables 3 and 4 report results from a sample of 13 countries over the period 1983-90. This sample allows an examination of trade, inward FDI and outward FDI as channels for international R\&D spillovers. All regressions use equation (6) as specification. ${ }^{12}$

\section{Table 3. Regression Results}

\begin{tabular}{|l|c|c|c|c|}
\hline Regression number & 3.1 & 3.2 & 3.3 & 3.4 \\
\hline \multirow{2}{*}{$\Delta \log S^{d}$} & -0.027 & -0.031 & -0.029 & -0.029 \\
& $(0.044)$ & $(0.047)$ & $(0.045)$ & $(0.046)$ \\
\hline \multirow{2}{*}{$\Delta \mathrm{G} 7 \log S^{d}$} & 0.063 & 0.072 & 0.058 & 0.069 \\
& $(0.042)^{+}$ & $(0.042)^{*}$ & $(0.041)^{+}$ & $(0.042)^{*}$ \\
\hline \multirow{2}{*}{$\Delta \mathrm{m} \log S^{f-C H}(\mathrm{KM})$} & 0.115 & & & 0.101 \\
& $(0.040)^{* * *}$ & & & $(0.041)^{* * *}$ \\
\hline \multirow{2}{*}{$\Delta \log S^{f-C H}(\mathrm{FDI})$} & & -0.039 & & -0.027 \\
& & $(0.031)$ & & $(0.033)$ \\
\hline \multirow{2}{*}{$\Delta \log S^{f-C H}(\mathrm{OFDI})$} & & & 0.034 & 0.030 \\
& & & $(0.018)^{* *}$ & $(0.018)^{*}$ \\
\hline \multirow{2}{*}{$\Delta \log S^{f}(\mathrm{UW})$} & 0.180 & 0.257 & 0.181 & 0.217 \\
& $(0.139)$ & $(0.149)^{*}$ & $(0.150)$ & $(0.140)^{+}$ \\
\hline \multirow{2}{*}{$\Delta \log \mathrm{H}$} & 0.114 & 0.105 & 0.120 & 0.106 \\
& $(0.064)^{*}$ & $(0.072)^{+}$ & $(0.072)^{*}$ & $(0.068)^{+}$ \\
\hline \multirow{2}{*}{$\log G A P$} & -0.045 & -0.048 & -0.048 & -0.046 \\
& $(0.013)^{* * *}$ & $(0.013)^{* * *}$ & $(0.013)^{* * *}$ & $(0.013)^{* * *}$ \\
\hline$R^{2}$ & 0.389 & 0.356 & 0.382 & 0.427 \\
\hline$R^{2}$ adjusted & 0.295 & 0.257 & 0.287 & 0.321 \\
\hline
\end{tabular}

Notes: The dependent variable is $\Delta \log$ TFP. All equations include unreported time-specific constants. Numbers in parentheses are heteroscedasticity-corrected standard errors. "***," “**," "*," and "+" indicate statistical significance at the 1\%,5\%,10\%, and 15\% levels, respectively. (Pooled Data 1984-90 for 13 OECD Countries, 91 Observations, OLS)

\footnotetext{
${ }^{12}$ First differencing of variables causes the regression period to be 1984-90.
} 
Table 4. Regression Results

\begin{tabular}{|l|c|c|c|c|}
\hline Regression number & 4.1 & 4.2 & 4.3 & 4.4 \\
\hline \multirow{2}{*}{$\Delta \log S^{d}$} & -0.041 & -0.028 & -0.020 & -0.032 \\
& $(0.048)$ & $(0.049)$ & $(0.050)$ & $(0.047)$ \\
\hline \multirow{2}{*}{$\Delta \mathrm{G} 7 \log S^{d}$} & 0.051 & 0.062 & 0.059 & 0.057 \\
& $(0.041)$ & $(0.042)^{+}$ & $(0.042)$ & $(0.042)$ \\
\hline \multirow{2}{*}{$\Delta \log S^{f-L P}(\mathrm{KM})$} & 0.046 & & & 0.050 \\
& $(0.016)^{* * *}$ & & & $(0.018)^{* * *}$ \\
\hline \multirow{2}{*}{$\Delta \log S^{f-L \mathrm{P}}(\mathrm{FDI})$} & & -0.005 & & -0.024 \\
& & $(0.017)$ & & $(0.018)$ \\
\hline \multirow{2}{*}{$\Delta \log S^{f-L P}(\mathrm{OFDI})$} & & & 0.012 & 0.008 \\
& & & $(0.014)$ & $(0.016)$ \\
\hline \multirow{2}{*}{$\Delta \log S^{f}(\mathrm{UW})$} & 0.129 & 0.197 & 0.210 & 0.158 \\
& $(0.173)$ & $(0.146)$ & $(0.148)$ & $(0.161)$ \\
\hline \multirow{2}{*}{$\Delta \log H$} & 0.099 & 0.120 & 0.114 & 0.098 \\
& $(0.064)^{+}$ & $(0.071)^{*}$ & $(0.069)^{*}$ & $(0.063)^{+}$ \\
\hline \multirow{2}{*}{$\log G A P$} & -0.041 & -0.048 & -0.045 & -0.038 \\
$\mathrm{R}^{2}$ & $(0.013)^{* * *}$ & $(0.014)^{* * *}$ & $(0.014)^{* * *}$ & $(0.013)^{* * *}$ \\
\hline $\mathrm{R}^{2}$ adjusted & 0.407 & 0.344 & 0.348 & 0.420 \\
\hline
\end{tabular}

Notes: The dependent variable is $\Delta \log$ TFP. All equations include unreported time-specific constants. Numbers in parentheses are heteroscedasticity-corrected standard errors. "***," "**," and "+" indicate statistical significance at the 1\%, 10\%, and 15\% levels, respectively. (Pooled Data 1984-90 for 13 OECD Countries, 91 Observations, OLS).

In Table 3 we apply the $\mathrm{CH}$ method to compute $S^{f}(K M), S^{f}(F D I)$, and $S^{f}(O F D I)$. In all regressions we find a strong "technology gap" effect that may be related to R\&D spillovers in disembodied forms. We also find that domestic R\&D capital is statistically significant in G7 countries but not in non-G7 countries. Regression (3.1) shows that the estimated coefficient on $S^{f}(K M)$ is statistically significant at the $1 \%$ level; thus the finding that capital goods trade is a spillover channel is robust in this smaller sample. In regression (3.2), we examine inward FDI as a spillover channel and find that the estimated coefficient on $S^{f}(F D I)$ is negative and statistically insignificant. Notice that $S^{f}(U W)$ is statistically significant at the $10 \%$ level in this regression. Regression (3.3) estimates the effect of outward FDI as a spillover channel; the estimated coefficient on $S^{f}(O F D I)$ is statistically significant at the 5\% level. In regression (3.4) we consider $S^{f}(K M), S^{f}(F D I), S^{f}(O F D I)$, and $S^{f}(U W)$ as simultaneous channels for R\&D spillovers. Results from this regression provide a summary of our findings: (1) capital goods trade is a significant spillover channel; (2) outward FDI is associated with international technology diffusion; (3) there is no evidence that inward FDI is a significant channel for 
international technology diffusion among industrial countries; (4) technology also diffuses in disembodied forms.

The finding that inward FDI is not a significant spillover channel needs qualification. There are data and methodology issues. It is well known that FDI is a poor proxy for activities of multinational enterprises, not to mention technologyrelated activities of multinational enterprises. Therefore, the finding could be a result of poor data. Moreover, inward FDI transmits technology in ways related to international trade and also in disembodied forms; hence its effect may well be captured in the trade variable $S^{f}(\mathrm{KM})$ and the disembodied spillover variable $S^{f}(\mathrm{UW}) .{ }^{13}$ Hejazi and Safarian (1999) found evidence that inward FDI transmits technology from six major industrial countries to other industrial countries. To identify the role of inward FDI as a spillover channel, one may need to measure the technology content of FDI. Xu (2000) is an attempt in that direction. He used technology transfer data to capture the technology intensity of FDI and found that U.S. multinational enterprises contributed to productivity growth of industrial countries.

In Table 4 we repeat the regressions of Table 3 with the LP measure of R\&D spillovers. As in Table 3, we find a statistically significant estimated coefficient on $S^{f}(\mathrm{KM})$, a statistically insignificant estimated coefficient on $S^{f}(\mathrm{FDI})$, and a strong "technology gap" effect. In contrast to Table 3, however, we find that $S^{f}(\mathrm{OFDI})$ is statistically insignificant. Thus, our result on outward FDI based on the $\mathrm{CH}$ measure of R\&D spillovers may not be robust when alternative measures of $R \& D$ spillovers are used. ${ }^{14}$ Notice that the estimated coefficient on $S^{f}(\mathrm{KM})$ is larger in regression (4.4) than in regression (4.1); this suggests that the LP measures of $S^{f}(\mathrm{FDI})$ and $S^{f}(\mathrm{OFDI})$ are not capturing the effects of R\&D spillovers related to FDI.

\section{Conclusions}

This paper examines international trade and foreign direct investment as channels for technology diffusion among industrialized countries. Using a sample of 21 OECD countries over the period 1971-90, we found that foreign R\&D spillovers embodied in capital goods trade had a sizable positive effect on a

\footnotetext{
${ }^{13}$ The inward FDI spillover variable is highly correlated with the capital good trade spillover variable. The correlation is 0.7886 when the $\mathrm{CH}$ measure is used and is 0.9117 when the LP measure is used. ${ }^{14} \mathrm{LP}$ (1996) found that outward FDI transmits technology between OECD countries. Their study uses FDI flow data and the result is obtained from a level regression.
} 
country's total factor productivity after controlling for the contributions of domestic R\&D, human capital, disembodied foreign $R \& D$ spillovers, and a "technology gap" effect. This finding is robust to two alternative measures of foreign R\&D spillovers; it provides strong empirical support for capital goods trade as a channel for international technology diffusion.

We investigated the role of FDI using a sample of 13 OECD countries over the period 1983-90. With foreign R\&D spillovers measured as in CH (1995), we found evidence that multinational enterprises (outward FDI) transmitted foreign technology back to the home country but no evidence that inward FDI was associated with technology spillovers. With R\&D spillovers measured as in LP (1996), we found that the spillover variables for both inward and outward FDI are statistically insignificant. Because of relatively low quality of FDI data, these results should be interpreted with caution.

Our investigation highlights a number of areas that require further research. First, the simple Cobb-Douglas production function approach, while useful in identifying empirical correlations between variables, ignores endogeneity of these variables. Future research needs to add more structures to the estimation. Second, there is a need to develop theoretical justifications for methods used in computing foreign R\&D spillovers. Third, more attention should be paid to econometric issues, for example, testing of cointegration in panel data. Of course, as any empirical research, the investigation of international $R \& D$ spillovers would benefit from availability of higher-quality data.

\section{References}

Barro, R.J. and J. Lee (1996), "International Measures of Schooling Years and Schooling Quality," American Economic Review 86, 218-223.

Barro, R.J. and X. Sala-i-Martin (1997), "Technology Diffusion, Convergence, and Growth," Journal of Economic Growth 2, 1-26.

Bernstein, J.I. and P. Mohnen (1998), "International R\&D Spillovers between U.S. and Japanese R\&D Intensive Sectors," Journal of International Economics 44: 315-338. Coe, D.T. and E. Helpman (1995), "International R\&D Spillovers," European Economic Review 39, 859-887.

Coe, D.T., E. Helpman, and A.W. Hoffmaister (1997), "North-South R\&D Spillovers," Economic Journal 107, 134-149.

Coe, D.T. and A.W. Hoffmaister (1999), “Are There International R\&D Spillovers Among Randomly Matched Trade Patterns ? A Response to Keller," IMF Working 
Paper No. 18, Washington, D.C.

Eaton, J. and S. Kortum (1996), "Trade in Ideas: Patenting and Productivity in the OECD,” Journal of International Economics 40, 251-278.

Eaton, J. and S. Kortum (1999), "International Technology Diffusion: Theory and Measurement," International Economic Review 40, 537-570.

Engelbrecht, H. (1997), "International R\&D Spillovers, Human Capital and Productivity in OECD Economies: An Empirical Investigation," European Economic Review 41, 1479-1488.

Hejazi, W. and E. Safarian (1996), "Trade, Investment and United States R\&D Spillovers," Canadian Institute for Advanced Research Working Paper, ECWP56.

Hejazi, W. and E. Safarian (1999), "Trade, Foreign Direct Investment, and R\&D Spillovers,” Journal of International Business Studies 30, 491-511.

Helpman, E. (1997), "R\&D and Productivity: The International Connection," Working Paper No. 6101 (NBER, Cambridge, MA).

Im, K.S., M.H. Pesaran, and Y. Shin (1997), "Testing for Unit Roots in Heterogeneous Panels," mimeo, Cambridge University.

Lichtenberg, F. and B. van Pottelsberghe de la Potterie (1996), "International R\&D Spillovers: A Re-examination,” Working Paper No. 5668 (NBER, Cambridge, MA).

Lichtenberg, F. and B. van Pottelsberghe de la Potterie (1998), "International R\&D Spillovers: A Comment," European Economic Review 42, 1483-1491.

Keller, W. (1998), “Are International R\&D Spillovers Trade-Related ? Analyzing Spillovers among Randomly Matched Trade Partners," European Economic Review 42, 1469-1481.

Xu, B. and J. Wang (1999), "Capital Goods Trade and R\&D Spillovers in the OECD," Canadian Journal of Economics 32, 1258-1274.

Xu, B. (2000), "Multinational Enterprises, Technology Diffusion, and Host Country Productivity Growth," Journal of Development Economics, 62, 477-493.

\section{Appendix}

\section{Distribution of Trade and FDI}

Table A1. Distribution of Capital Goods Imports (\%)

\begin{tabular}{|l|c|c|c|c|c|c|r|}
\hline US & Japan & Germany & France & UK & Italy & Canada & \\
\hline US & & 45.92 & 11.21 & 3.68 & 5.63 & 2.37 & 26.41 \\
\hline Japan & 55.85 & & 24.63 & 3.43 & 5.17 & 3.62 & 1.01 \\
\hline
\end{tabular}


Table A1. Distribution of Capital Goods Imports (\%)

\begin{tabular}{|l|c|c|c|c|c|c|c|}
\hline US & Japan & Germany & France & UK & Italy & Canada & \\
\hline Germany & 13.88 & 18.64 & & 20.90 & 11.27 & 11.38 & 0.67 \\
\hline France & 18.01 & 11.42 & 33.34 & & 10.83 & 16.59 & 0.60 \\
\hline UK & 16.79 & 14.64 & 30.69 & 12.74 & & 7.55 & 1.19 \\
\hline Italy & 7.51 & 6.25 & 42.09 & 20.96 & 8.64 & & 0.38 \\
\hline Canada & 77.87 & 12.09 & 3.61 & 1.73 & 1.75 & 0.80 & \\
\hline US & Japan & Germany & France & UK & Italy & Canada & \\
\hline Australia & 35.38 & 36.57 & 9.28 & 2.16 & 6.67 & 2.98 & 1.64 \\
\hline Austria & 6.14 & 11.19 & 57.34 & 5.45 & 3.34 & 7.50 & 0.53 \\
\hline Netherlands & 13.15 & 10.13 & 38.21 & 9.86 & 13.59 & 5.34 & 1.20 \\
\hline Norway & 20.65 & 11.38 & 24.42 & 5.22 & 11.37 & 3.87 & 0.78 \\
\hline Sweden & 18.38 & 13.33 & 33.43 & 7.50 & 9.27 & 6.33 & 0.83 \\
\hline Switzerland & 8.21 & 11.44 & 45.25 & 9.42 & 5.36 & 9.63 & 0.20 \\
\hline
\end{tabular}

(Import Shares of Row Country in 13 OECD Countries, 1990)

Table A2. Distribution of Inward FDI (\%)

\begin{tabular}{|l|c|r|r|r|r|r|c|}
\hline & US & Japan & Germany & France & \multicolumn{1}{c|}{ UK } & Italy & Canada \\
\hline US & & 25.02 & 9.14 & 4.94 & 27.00 & 0.81 & 11.05 \\
\hline Japan & 69.70 & & 8.12 & 1.35 & 7.12 & 2.70 & 1.57 \\
\hline Germany & 35.06 & 6.36 & & 6.46 & 9.79 & 3.53 & 1.19 \\
\hline France & 26.31 & 3.92 & 16.15 & & 17.94 & 6.61 & 1.76 \\
\hline UK & 46.03 & 6.93 & 4.58 & 5.77 & & 1.37 & 5.90 \\
\hline Italy & 23.16 & 1.57 & 12.76 & 11.17 & 11.23 & & 0.52 \\
\hline Canada & 69.10 & 4.50 & 3.38 & 3.16 & 12.75 & 0.37 & \\
\hline Australia & 30.25 & 19.72 & 2.73 & 1.51 & 35.19 & 0.28 & 4.42 \\
\hline Austria & 11.72 & 2.12 & 52.97 & 1.95 & 4.73 & 3.28 & 0.43 \\
\hline Netherlands & 26.84 & 9.74 & 9.45 & 12.07 & 15.88 & 3.77 & 1.32 \\
\hline Norway & 44.20 & 4.41 & 5.64 & 8.26 & 4.77 & 0.09 & 0.49 \\
\hline Sweden & 19.34 & 0.48 & 8.53 & 2.41 & 7.69 & 0.34 & 0.31 \\
\hline Switzerland & 41.00 & 3.55 & 10.06 & 10.53 & 6.05 & 10.45 & 1.72 \\
\hline
\end{tabular}

Inward FDI Shares of Row Country in 13 OECD Countries, 1990)

Table A3. Distribution of Outward FDI (\%)

\begin{tabular}{|l|c|c|c|r|r|c|c|}
\hline & US & Japan & Germany & France & UK & Italy & Canada \\
\hline US & & 5.50 & 9.88 & 5.54 & 25.15 & 3.68 & 26.44 \\
\hline Japan & 68.11 & & 3.60 & 1.66 & 7.60 & 0.50 & 3.46 \\
\hline Germany & 42.96 & 2.22 & & 11.79 & 8.67 & 7.02 & 4.48 \\
\hline France & 32.49 & 0.52 & 8.84 & & 15.30 & 8.60 & 5.87 \\
\hline
\end{tabular}


Table A3. Distribution of Outward FDI (\%)

\begin{tabular}{|l|c|c|c|r|r|c|c|}
\hline & US & Japan & Germany & France & UK & Italy & Canada \\
\hline UK & 57.69 & 0.89 & 4.35 & 5.96 & & 2.81 & 7.69 \\
\hline Italy & 14.03 & 2.74 & 12.78 & 17.89 & 9.64 & & 1.83 \\
\hline Canada & 72.16 & 0.60 & 1.61 & 1.79 & 15.52 & 0.39 & \\
\hline Australia & 36.99 & 0.70 & 0.86 & 0.16 & 51.44 & 0.37 & 4.45 \\
\hline & US & Japan & Germany & France & UK & Italy & Canada \\
\hline Austria & 15.24 & 0.00 & 49.39 & 4.00 & 3.28 & 3.14 & 2.78 \\
\hline Netherlands & 46.00 & 0.79 & 11.14 & 8.91 & 17.08 & 3.94 & 2.76 \\
\hline Norway & 14.07 & 0.04 & 5.43 & 3.34 & 25.14 & 1.00 & 8.50 \\
\hline Sweden & 25.98 & 0.00 & 7.05 & 4.85 & 10.57 & 5.53 & 1.93 \\
\hline Switzerland & 25.48 & 1.38 & 18.15 & 6.47 & 16.41 & 14.50 & 3.11 \\
\hline
\end{tabular}

(Outward FDI Shares of Row Country in 13 OECD Countries, 1990) 